\title{
Papilloedema with retinal haemorrhages in idiopathic intracranial hypertension
}

\author{
Osman Younus (ㄱ), Prodromos Savides
}

Ophthalmology, University Hospital Hairmyres, East Kilbride, UK

\section{Correspondence to} Dr Osman Younus; osmanyounus@hotmail.com

Accepted 27 January 2022
Check for updates

(C) BMJ Publishing Group Limited 2022. No commercial re-use. See rights and permissions. Published by BMJ.

To cite: Younus 0,
Savides P. BMJ Case
Rep 2022;15:e248912.
doi:10.1136/bcr-2022-
248912

\section{DESCRIPTION}

A woman in her 20's was admitted with a 2-week history of severe headaches associated with vomiting, tinnitus, diplopia and transient visual obscurations. Her medical history was significant for obesity and oestrogen oral contraceptive use. On examination, her blood pressure measured 135/75 mm Hg. Neurological examination was unremarkable. Fundoscopy revealed papilloedema and retinal bleeding. A full blood count, clotting, renal, liver and bone profiles were all within normal limits. Cerebral MRI and CT venography were unremarkable.

On day 4 of admission, she was referred for ophthalmological assessment. Best corrected visual acuity was 6/19 in both eyes. Pupils, tonometry and ocular motility were normal in both eyes. Dilated retinal examination confirmed bilateral Frisén Grade 5 disc oedema, retinal vein tortuosity with congestion and widespread retinal haemorrhages (figure 1).

A subsequent lumbar puncture measured an opening pressure of $69 \mathrm{~cm} \mathrm{H}_{2} \mathrm{O}$, which was reduced to $35 \mathrm{~cm} \mathrm{H} \mathrm{H}_{2} \mathrm{O}$. The cerebrospinal fluid (CSF) fluid constituents were normal. CSF viral studies and oligoconal band analysis were negative. We performed additional investigations for serum B12 and folate, antinuclear antibody, dsDNA, anti-cardioplin antibodies, Haemoglobin $\mathrm{A} 1 \mathrm{c}$ and protein electrophoresis, all of which demonstrated no further abnormalities.

A new diagnosis of idiopathic intracranial hypertension (IIH) was made. Oral acetazolamide was commenced at $250 \mathrm{mg}$ two times a day. At 2-month

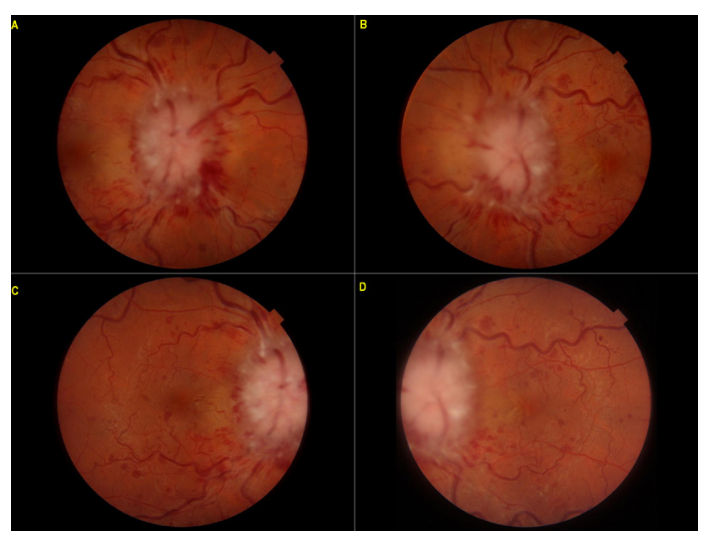

Figure 1 Colour fundus photographs of both eyes. (A) right and (B) left severe optic disc swelling with peripapillary haemorrhages and cotton wool spots. (C) right and (D) left engorged, tortuous retinal veins with retinal haemorrhages.

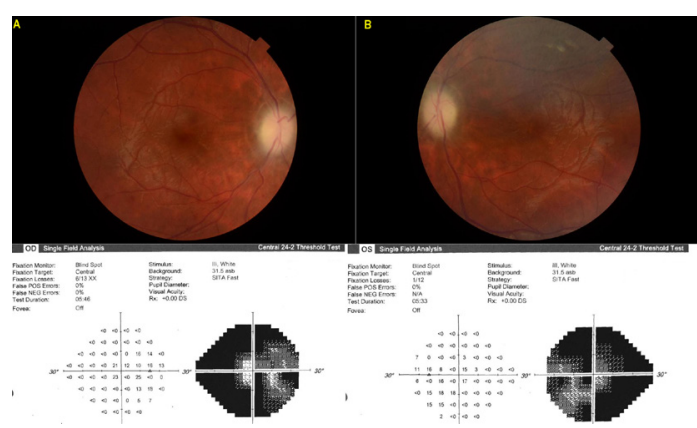

Figure 2 Colour fundus photographs and corresponding visual fields of the right eye (A) and left eye (B). There is bilateral atrophic papilloedema with visual field constriction.

follow-up, she was asymptomatic. Visual acuity improved to 6/9.5 in the right eye and remained static at 6/19 in the left eye. The retinopathy had resolved and the optic discs developed atrophic papilloedema (figure 2). Humphrey visual fields demonstrated marked constriction bilaterally.

We describe a patient presenting with IIH and haemorrhagic retinopathy, which is an unusual combination. The differential diagnoses included bilateral central retinal vein occlusions, systemic hyperviscosity and hypercoagulability syndromes, and blood dyscrasias. The improvement in the haemorrhages with reduction of the intracranial pressure indicated that IIH was the cause. Further investigations did not reveal an underlying systemic disorder. There are few case reports of retinal vascular changes in association with IIH, some due to central retinal vein occlusion, ${ }^{12}$ and others due to pre-retinal and vitreous haemorrhage. ${ }^{3}$ It has been speculated that an acute rise in intracranial pressure compresses the central retinal vein in the region of the optic nerve head. ${ }^{4}$ This mechanism would explain the observed venous tortuosity and distribution of haemorrhages along the vascular arcades.

Our patient presented with a reduced visual acuity. This point is significant, because acute papilloedema is often associated with preserved vision. We attributed the acute visual loss to haemorrhagic retinopathy. Other retinal causes of visual loss in IIH include macula oedema, subretinal fluid, retinal artery and vein occlusion and choroidal infarction. ${ }^{5}$ Despite the normal retinal appearances at follow-up, our patient's visual acuity remained limited. The development of bilateral disc atrophy and concentric visual field loss were consistent with optic neuropathy. This reflects the differing aetiologies of visual loss in acute and chronic IIH. 
The diagnosis of IIH relies on skilled direct ophthalmoscopy. Clinicians' lack of confidence with using the direct ophthalmoscope has been well documented. ${ }^{6}$ Retrospective studies suggest that up to $20 \%$ of IIH diagnoses are made without funduscopy. ${ }^{7}$ Retinal changes may be an underreported aspect of diagnosis.

The combination of papilloedema and retinal vascular changes from IIH is rare. This may cause acute visual loss, but is reversible with timely reduction of raised intracranial pressure. Patients, however, may be left with long-term sequelae of optic atrophy. We emphasise the importance of direct fundus examination in all cases of suspected IIH.

\section{Learning points}

- Idiopathic intracranial hypertension (IIH) may present with papilloedema and haemorrhagic retinopathy.

- IIH presenting with a reduced visual acuity may be unrelated to papilloedema, emphasising the importance of a direct fundus examination.

- Timely reduction of raised intracranial pressure can relieve the vascular haemorrhage.

Contributors All authors satisfy the ICMJE criteria for authorship. OY contributed to conceptualisation, writing original draft. PS contributed to writing-reviewing and editing.
Funding The authors have not declared a specific grant for this research from any funding agency in the public, commercial or not-for-profit sectors.

Competing interests None declared.

Patient consent for publication Consent obtained directly from patient(s).

Provenance and peer review Not commissioned; externally peer reviewed.

Case reports provide a valuable learning resource for the scientific community and can indicate areas of interest for future research. They should not be used in isolation to guide treatment choices or public health policy.

\section{ORCID iD}

Osman Younus http://orcid.org/0000-0003-1677-5284

\section{REFERENCES}

1 Chern S, Magargal LE, Brav SS. Bilateral central retinal vein occlusion as an initial manifestation of pseudotumor cerebri. Ann Ophthalmol 1991;23:54-7.

2 Voldman A, Durbin B, Nguyen J, et al. Fulminant idiopathic intracranial hypertension and venous stasis retinopathy resulting in severe bilateral visual impairment. Eur J Ophthalmol 2017;27:e25-7.

3 Raevis J, Elmalem VI. Pseudotumor cerebri syndrome causing a Terson like syndrome. Am J Ophthalmo/ Case Rep 2020:20:100993.

4 Galvin R, Sanders MD. Peripheral retinal haemorrhages with papilloedema. Br J Ophthalmol 1980;64:262-6.

5 Nichani P, Micieli JA. Retinal manifestations of idiopathic intracranial hypertension. Ophthalmol Retina 2021;5:429-37.

6 Mackay DD, Garza PS, Bruce BB, et al. The demise of direct ophthalmoscopy: a modern clinical challenge. Neurol Clin Pract 2015;5:150-7

7 Fisayo A, Bruce BB, Newman NJ, et al. Overdiagnosis of idiopathic intracranial hypertension. Neurology 2016;86:341-50.

Copyright 2022 BMJ Publishing Group. All rights reserved. For permission to reuse any of this content visit

https://www.bmj.com/company/products-services/rights-and-licensing/permissions/

BMJ Case Report Fellows may re-use this article for personal use and teaching without any further permission.

Become a Fellow of BMJ Case Reports today and you can:

- Submit as many cases as you like

Enjoy fast sympathetic peer review and rapid publication of accepted articles

- Access all the published articles

- Re-use any of the published material for personal use and teaching without further permission

Customer Service

If you have any further queries about your subscription, please contact our customer services team on +44 (0) 2071111105 or via email at support@bmj.com.

Visit casereports.bmj.com for more articles like this and to become a Fellow 